\title{
Diadorim, Palas Atena sertaneja
}

\author{
Gabriela Guimarães Gazzinelli ${ }^{1}$
}

"Sertão é onde manda quem é forte, com as astúcias.

Deus, mesmo, se vier, que venha armado."

João Guimarães Rosa

Resumo: Este artigo procura mostrar que a caracterização da personagem Diadorim, de Guimarães Rosa, evoca, em diferentes passos do romance Grande sertão: veredas, a tradição literária sobre Palas Atena. Entre os elementos de comparação incluo: (i) questões de origem e filiação; (ii) olhos glaucos ou verdes; (iii) símiles de pássaros, chuva, rios e neblina; (iv) analogia entre Atena e Ares, de um lado, e Diadorim e Hermógenes, de outro, no que tange à condução da guerra. O paralelo entre Diadorim e Atena é uma manifestação do processo mais geral de mitificação do Sertão na literatura brasileira, objeto de algumas considerações ao final do texto.

Palavras-chave: Diadorim, Guimarães Rosa, Palas Atena, Sertão. Deusas.

Abstract: In this paper I examine passages concerning the character Diadorim, from The Devil to Pay in the Backlands, in light of the literary tradition on Pallas Athena. I dwell on the following elements of comparison: (i) questions regarding origins and paternity; (ii) green or flashing eyes; (iii) bird, rain, river, and fog similes; (iv) the analogy between Ares and Athena on the one hand, and Diadorim and Hermogenes on the other, with regards to warfare. I further argue that the parallel between Diadorim and Athena instantiates a more general process through which the "Sertão" is represented mythically in Brazilian literature.

Keywords: Diadorim, Guimarães Rosa, Pallas Athena, Sertão, Goddesses.

\section{Introdução}

Ao tematizar o Sertão, Guimarães Rosa transcendeu a sua dimensão geográfica, evocando temas como o divino, a origem do cosmos, as leis da natureza, a língua. Nas narrativas, decanta-se uma visão de mundo singular, integrada por especulações filosóficas, religiosas e científicas. O Sertão tornou-se, com efeito, um palimpsesto literário em que elementos míticos e metafísicos muitas vezes sobrepõem-se aos seus aspectos

\footnotetext{
${ }^{1}$ Doutora em Estudos Portugueses e Brasileiros pela Brown University, Mestre em Filosofia pela UFMG e em Diplomacia pelo Instituto Rio Branco. Com agradecimentos a Loraine de Oliveira, pelo convite gentil para participar deste número da revista Das questões, a Luiz Fernando Valente, pelo excelente curso sobre a literatura do Sertão, e a Eduardo C. Lourenço de Lima, pela troca de ideias sem fim.
} 
naturais. Transparece uma preocupação em conhecer os princípios da realidade e mesmo de uma "suprarrealidade", como a chamou Guimarães Rosa, em que o humano confina com o divino e a genealogia remete à teogonia.

Neste artigo, apresento uma leitura do romance Grande sertão: veredas que aproxima a personagem Diadorim da deusa grega Palas Atena. Procurarei mostrar que a caracterização da personagem rosiana evoca, em diferentes passos, a tradição literária sobre Palas. Paralelos significativos se apresentam nas descrições do jagunço "belo feroz" (p. 67), "delicado e terrível" (p. 377), "astuto" (p. 67), "sério, testalto" (p. 157), "esmarte, correto em seu bom proceder" (p. 161), de "coragem inteirada em peça” (p. 92), "que a brio pelejava por espertar" (p. 327). É importante deixar notado, de saída que, como tentarei mostrar, a convergência entre Palas e Diadorim vai muito além de meras alusões literárias e da analogia óbvia entre duas guerreiras; ela também aparece, por exemplo, no âmbito biográfico e na amizade protetora com Riobaldo, relação essa estruturante no transcurso da obra romanesca.

Antes de prosseguir, faço duas observações. Primeiro, dada a riqueza de referências que se constelam no romance, esta é uma análise que se propõe a elucidar tão só parte da obra. Como sentencia o narrador rosiano, "no real da vida, as coisas acabam com menos formato" (p. 7o). Em segundo lugar, esclareço que as similitudes entre Diadorim e Atena que serão assinaladas não compõem um quadro de isomorfismo e, muito menos, de identidade. Há antes uma inspiração livre, com evidentes discrepâncias. Discrepâncias que culminam na imortalidade de Palas e na morte de Diadorim, humana no final das contas, em que pese o fato de Riobaldo "sentir que Diadorim não era mortal"(p. 488). Mas acredito que deslindar essa semelhança nos permite aguçar, ainda que parcialmente, o nosso entendimento do romance, além de vislumbrar a beleza do processo de apropriação e tradução, por parte de Guimarães Rosa, de motivos consagrados no cânone literário, concedendo-lhes nuanças e conotações novas.

O exercício de cotejar a heroína sertaneja com a deusa olímpica não deve provocar estranhamento. $\mathrm{O}$ autor tinha vivo interesse pela poesia épica antiga, que está documentado em correspondências, na marginalia a livros que integraram sua biblioteca e nos manuscritos de seu acervo. Segundo Ana Luiza Martins Costa, Rosa chegou mesmo a ter um "Caderno Homero", composto de trinta-e-cinco páginas datilografadas, com anotações tiradas de suas leituras da poesia épica grega. O caderno "contém a cópia de inúmeras passagens dos poemas e alguns breves comentários sobre o herói, a linguagem e 
a narrativa épica" (2001/2002, p. 79). Três seções integram o dito caderno: duas sobre a Ilíada, uma das quais só de epítetos, e a última, menor, sobre a Odisseia. Na epistolografia de Rosa há igualmente registro do interesse dele por Homero. Nesse sentido, em carta a Álvaro Lins, de 16 de novembro de 1950, remetida de Paris, onde estava em missão diplomática, Rosa comenta:

O contato sentimental com a velha Grécia de Minerva e Possêidon abriu-me tão dilatado apetite, que, mal cheguei aqui, precisei de atacar e reler Ilíada e Odisséia, mas linha a linha, anotando, e, principalmente, amando aqueles longos espaços encantados, ouvindo o chocar dos bronzes ou me perdendo a ver aquele mar dos mares, cor de vinho, do qual emergem deuses "como gaivotas sobre a asa”... (apud Ana Luiza Martins Costa, 2001/2002, p. 79).

Além de revelar o apreço do escritor por Homero, a passagem destaca a proeminência dos deuses no imaginário épico.

Deixarei de lado especulações de ordem biográfica, que buscariam apoio nas impressões de leitura registradas pelo autor, para investigar os desdobramentos propriamente literários desse "contato sentimental com a velha Grécia de Minerva e Possêidon”. O que me permite tomar este caminho é que, mesmo se não tivéssemos à nossa disposição o "Caderno Homero" ou nada semelhante, a convergência entre Diadorim e Palas Atena pode ser estabelecida materialmente, a partir do próprio Grande sertão: veredas. O leitor certamente já conhece, dos escritos de Guimarães Rosa, variadas alusões à literatura grega. Por exemplo, em Sagarana, no conto "Minha gente", encontra-se um personagem "ledor de Homero" (p. 176). Em outro conto da coletânea, "A hora e a vez de Augusto Matraga", identificam-se características do herói grego - como o amor à glória e a valorização da bela morte - na composição dos personagens Augusto Matraga e Joãozinho Bem-Bem. Mas é em Grande sertão: veredas e no Corpo de baile que o diálogo com a tradição antiga está mais arraigado. Nessas obras monumentais - que, à maneira da épica, buscam abarcar as diferentes manifestações da existência sertaneja - além das alusões pontuais, de identificação mais imediata, estão incorporados também elementos de estilo e de estruturação da narrativa, cuja apreensão em termos homéricos requer uma leitura mais cuidadosa.

Na próxima seção, farei breve apanhado das menções a Palas Atena na fortuna crítica de Grande sertão: veredas. Em seguida, passarei a três eixos de comparação: (i) 
figurações de Palas; (ii) Diadorim belígera; e (iii) a neblina de Diadorim. Por fim, à guisa de contextualização, tematizarei a mitificação do universo sertanejo por Guimarães Rosa. Com esse intuito, procurarei apontar elementos de diálogo de sua obra com a tradição sertaneja que a antecedeu, que remonta às crônicas de viajantes que passaram pelo Brasil desde o século XVI e continua nos escritos de José de Alencar, Euclides da Cunha e Graciliano Ramos. O sentido dessa digressão será mostrar que a aproximação de Diadorim e Palas é um caso específico de um processo mais amplo de mitificação do universo sertanejo.

\section{Diadorim e Atena, a sugestão de uma semelhança}

$\mathrm{Na}$ fortuna crítica de Grande sertão: veredas, alguns comentadores falam, de passagem, da semelhança de Diadorim com Palas Atena. Parte deles tão só inscreve a deusa grega numa lista de "donzelas virgens" consagradas no cânone literário, sem todavia aprofundar-se em exercícios comparativos (cf. Edilene Ribeiro Batista, 2016, e Ricardo Iannace, 1999). Outros dedicam algumas linhas a um ou outro traço de similitude a fim de informar discussões de temas diversos. Márcia Tiburi (2013), por exemplo, insere Diadorim "na linhagem de Palas Atena". Para a comentadora, "Diadorim seria "filha de um pai sem mãe", num paralelo ao nascimento de Atena da cabeça de Zeus, por "partenogênese masculina” (p. 202, n. 42).

Por sua vez, Márcio Seligmann-Silva (2009), além de aludir à ausência de mãe na história de Diadorim, aproxima a personagem sertaneja de Palas Atena em virtude do papel da deusa no julgamento de Orestes na peça Eumênides, de Ésquilo:

Palas Atena vota no partido dos homens, de Zeus, Apolo e Orestes, contra a apelação das Fúrias, que, defendendo Clitemnestra, voltam-se para a mãe delas, a Noite. Em Grande sertão: veredas encontramos também uma Palas Atena que, como na tragédia de Ésquilo, é apresentada como alguém que não teve mãe: Diadorim. Este personagem, híbrido como a deusa grega, também vota no partido dos homens. (p. 142)

Cumpre notar, porém, que Seligmann-Silva não empreende uma comparação sistemática. Primeiro, porque a aproximação sugerida por ele está circunscrita a um único 
episódio do romace, o julgamento de Zé Bebelo, a cuja análise passa em seguida. Em segundo lugar, porque Diadorim não desempenha no julgamento de Zé Bebelo o papel decisivo do "voto de Minerva" que Palas Atena desempenha no julgamento de Orestes. A bem da verdade, Diadorim não vota e nem mesmo chega a discursar durante o julgamento. Além disso, a preocupação do artigo é outra, destrinçar o romance como gesto testemunhal e confessional.

Por fim, no artigo já citado "Homero no Grande Sertão” e em “Diadorim, delicado e terrível” (2002), Ana Luiza Martins Costa apresenta levantamento cuidadoso dos traços de Diadorim que evocam as virtudes do guerreiro épico:

"Em chamariz de finta" tem o sentido de manobra astuta e arrisca da de quem adota a tática do logro e da dissimulação em vez do enfrentamento direto. [...] Este símile é um caso exemplar, porque interage plenamente com a narrativa. Por um lado, retoma e condensa, colocando em claro relevo, dois importantes atributos desse personagem de Riobaldo: o Diadorim de "esmerados esmartes olhos", que se mostra "astuto" quando enfrenta o próprio bando de jagunços, disputando o lugar de chefe ("ele era mestre nisso"); e o menino dissimulado que enfrenta um mulato indecente com "fala" e "jeito" que "imitavam de mulher". Por outro lado, através da imagem da fêmea-que-engana e do risco de morte contido em seu ardil, o símile antecipa o desfecho da estória, que junta o feminino com o disfarce e a morte, revelando Diadorim como mestre das aparências enganosas. (2001/2002, p. 109)

Estas qualidades, que definem Diadorim como homem viril, colocam-no lado a lado com os heróis épicos da Ilíada, os quais são constantemente comparados a animais ferozes (que atacam sozinhos ou em bando - como o leão, emblema das virtudes guerreiras; touro, leopardo, pantera; lobos, javalis, cães) e a forças da natureza (fogo/incêndio,tempestade/furacão,ou a voragem de um rio). Tanto na Ilíada quanto no Grande sertão: veredas, bem mais do que um simples ornamento, essas comparações expressam e põem em evidência a natureza violenta do ardor guerreiro: o desejo de matar (Loraux, 1994, p. 29-48). Elas explicitam um laço de identidade, uma qualidade comum entre homens e feras que incide sobre a aparência física e o comportamento, e que os leva a matar e arriscar a vida no combate. (2002, p. 49)

Embora a comentadora não chegue a explicitar a semelhança da personagem rosiana com Palas Atena, no retrato que esboça do jagunço - que "sabia era a guerra” (p. 
275), combinando elementos femininos e masculinos, valentia e beleza, delicadeza e terror, astúcia e coragem - despontam características associadas à deusa.

\section{Figurações de Palas}

A similitude entre Diadorim e Palas Atena se nos afigura em diferentes passos descritivos. Na economia romanesca, tais descrições cumprem um papel estruturante na narrativa ao lançar luz sobre disposições anímicas e repisar memórias afetivas. A interioridade da personagem se pode deduzir a partir de seus efeitos tangíveis, objeto de descrição: há certa homologia entre a alma e a exterioridade representada. Nas palavras de Georg Lukacs, em certas obras, as descrições são "inerentemente significativas em razão do envolvimento direto das personagens no evento e do sentido social geral que emerge nos desdobramentos das vidas das personagens" (p. 116). Além de revelar algo dos movimentos íntimos da alma, certas descrições cumprem o papel de ressignificar simbolicamente a realidade objetiva representada.

No caso de Diadorim, já o relato de sua origem parece glosar a tradição sobre Palas Atena. Como observam Tiburi e Seligmann-Silva, a ausência de uma figura materna na vida de Diadorim remete ao nascimento da deusa, que segundo a tradição teria nascido da testa de Zeus. Nesse sentido, Diadorim revela a Riobaldo: "pois a minha [mãe] eu não conheci" (p. 31). Algumas páginas adiante, a moça jagunço retoma o assunto, "nossa destinação é de glória. Em hora de desânimo, você lembra de sua mãe; eu lembro de meu pai” (p. 36).

Como segundo passo nesse paralelo biográfico, verifica-se que, em diferentes momentos, a caracterização do pai de Diadorim, Joca Ramiro, faz-nos pensar em Zeus, pai de Atena. A primeira vez em que surge na narrativa, o chefe dos jagunços é assim apresentado:

Espiei Diadorim, a dura cabeça levantada, tão bonito tão sério. E corri lembrança em Joca Ramiro: porte luzido, passo ligeiro, as botas russianas, a risada, os bigodes, o olhar bom e mandante, a testa muita, o topete de cabelos anelados, pretos, brilhando. Como que brilhava ele todo. Porque Joca Ramiro era mesmo assim sobre os homens, ele tinha uma luz, rei da natureza. Que Diadorim fosse o filho, agora de vez me alegrava, me assustava. (p. 28-29) 
A ênfase na ascendência de Joca Ramiro sobre os homens e a natureza remete à tradição antiga sobre o deus olímpico.

Outros trechos enfatizam igualmente a grandeza e a autoridade do pai de Diadorim:

Adrede Joca Ramiro estava de braços cruzados, o chapéu dele se desabava muito largo. Dele, até a sombra, que a lamparina arriava na parede, se trespunha diversa, na imponência, pojava volume. E vi que era um homem bonito, caprichado em tudo. Vi que era homem gentil. (p. 98)

E Joca Ramiro. A figura dele. [...] E ele era um homem de largos ombros, a cara grande, corada muito, aqueles olhos. Como é que fvou dizer ao senhor? Os ca elo pretos, anelados? O chapeeu bonito. Ele era um homem. Liso bonito. Nem tinha mais outra coisa em que se reparar. A gente olhava, sem pousar os olhos. [...] Uma voz sem pingo de dúvida nem tristeza. Uma voz que continuava. (p. 216)

"Não é que ele é chefe de todos? Não é que é mandante?" -

Diadorim me perguntava (p. 217)

Joca Ramiro era mesmo o tutumumbuca, grande maioral. (p. 231) Joca Ramiro aí disse, em final. E se levantou, num de repente. Ah, quando ele levantava, puxava as coisas consigo, parecia - as pessoas, o chão, as árvores desencontradas. E todos também, ao em um tempo - feito um boi só, um gado em círculos, um relincho de cavalo. (p. 245)

Nas descrições, Joca Ramiro guarda similitudes com Zeus em diferentes planos. A semelhança física ("o porte luzido, ... o olhar bom e mandante, a testa muita, o topete de cabelos anelados, pretos, brilhando") poderia ser fortuita, mas as referências a outras qualidades do pai do Diadorim já deixam menos margem ao acaso. Ao se afirmar que Joca Ramiro "era mesmo assim sobre os homens, ele tinha uma luz, rei da natureza" e que "até a sua sombra [...] se trespunha [...] na imponência", que era "chefe de todos", "mandante", "grande maioral" e que, "quando levantava" puxava tudo consigo, a insistência sobre seu poder de mando reforça a hipótese de uma inspiração no rei dos deuses olímpicos para a concepção do chefe dos jagunços. Mesmo o emprego do adjetivo "tutumumbuca", que significa "mandachuva" e que parece conter uma onomatopeia para o trovão, nos recorda Zeus enquanto deus do céu e do trovão. 
Cumpre ainda observar que o nome de jagunço de Diadorim, "Reinaldo", talvez contenha uma referência cifrada a seu pai Joca Ramiro, por meio da composição da palavra “rei” com o posfixo germânico "aldo", comumente empregado para derivação onomástica.

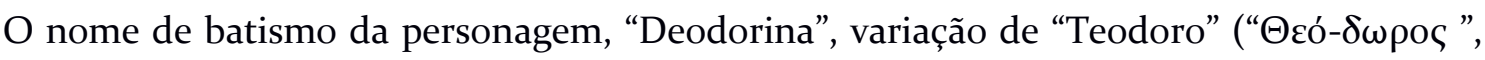
presente de deus, em grego) também teria um radical alusivo a Joca Ramiro, o "Deo-", variante de "Theo-" cujo sentido é "deus". Por sua vez, o apelido carinhoso "Diadorim" parece conter uma referência nominal a Zeus. Em minha hipótese, deriva-se da

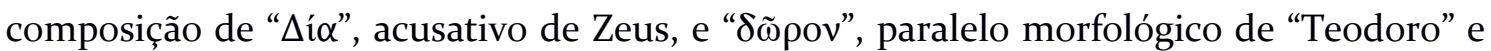
"Zeusdoro", presente de deus, presente de Zeus, ou melhor, "presentinho” de Zeus, em vista do emprego do diminutivo abreviado “-im”, característico de dialetos de Minas Gerais ${ }^{2}$

Analogamente, Diadorim é também descrita em termos que fazem pensar na filha do deus olímpico Palas Atena, enquanto guerreira virgem e andrógina. A moça guarda traços minérveos em detalhes de sua composição, como as referências aos olhos verdes e à testa alta ou à luz que tinha, "o que Diadorim reslumbrava" (p. 358). São ilustrativos também os símiles de pássaros e de fenômenos naturais relacionados ao elemento água. Tais passagens parecem tomar, como mote, epítetos para Atena/Minerva na literatura antiga ${ }^{3}$.

Em Homero, glaucópis é o epíteto de uso mais frequente para caracterizar Palas. Segundo o dicionário Liddell-Scott-Jones, o adjetivo glaucos teria significado, num primeiro momento, "brilhante", sendo empregado principalmente para descrever o "mar". O verbete atesta ainda ocorrências para qualificar "lago", "lua", "estrelas", "aurora" e "olhos". A reiterada associação do adjetivo com o mar teria resultado, por derivação, no uso do termo para referir uma cor, de matiz incerto: o dicionário registra "azulesverdeado", "cinza" e "oliva". Glaucópis, de olhos "glaucos", é traduzido ora como "de olhos brilhantes" ora como "de olhos esverdeados/verde-cinzentos/verde-azulados". Na seção "Ilias", do Caderno Homero, Rosa colige, entre outros epítetos homéricos, traduções, para o inglês e alemão, de glaucópis: "Atena: Athene of the flashing eyes; bright-eyed Athene (glaukópis);

\footnotetext{
${ }^{2}$ Em algumas interpretações, o nome "Diadorim" resultaria da composição da preposição "diá' do grego antigo, que significa "por meio de", com a palavra "dor". Outros identificam em "Dia" abreviação de "diabo", sendo "Diadorim" uma antítese de "Deodorina", que contém o radical "Deo-" em referência a "Deus".

${ }^{3}$ Sobre o uso literário de epítetos, o próprio Guimarães Rosa, em seu "Caderno Homero", imputa-lhes a função de "estribilho e leitmotiv: a necessidade de recordar ao ouvinte (as rapsódias eram declamadas) quem eram as personagens" (apud Martins Costa, 2001/2002, p. 97).
} 
unsleeping Child of aegis-bearing Zeus. Athene, die Göettin mit leuchtenden Augen (glaukópis); Pallas Athene gewaltig leuchtende Augen; die Helläugige." (apud Martins Costa, 2001/2002, p. 84 e 114).

São muitas as passagens de Grande sertão: veredas que descrevem os olhos de Diadorim. Algumas parecem glosar o epíteto homérico:

Que vontade era de pôr meus dedos, de leve, o leve, nos meigos olhos dele, ocultando, para não ter de tolerar de ver assim o chamado, até que ponto esses olhos, sempre havendo, aquela beleza verde, me adoecido, tão impossível. (p. 36)

Buriti, minha palmeira, / lá na vereda de lá:/casinha da banda esquerda, / olhos de onda do mar... Mas os olhos verdes sendo os de Diadorim. (p. 40-41)

Era um menino bonito, claro, com a testa alta e os olhos aosgrandes, verdes. (p. 86).

Olhei: aqueles esmerados esmartes olhos, botados verdes, de folhudas pestanas, luziam um efeito de calma, que até me repassasse. (p. 81)

Naqueles olhos e tanto de Diadorim, o verde mudava sempre, como a água de todos os rios em seus lugares ensombrados. Aquele verde, arenoso, mas tão moço, tinha muita velhice, muita velhice, querendo me contar coisas que a idéia da gente não dá para se entender - e acho que é por isso que a gente morre. (p. 252)

Os olhos [...] que cresciam sem beira, dum verde dos outros verdes, como o de nenhum pasto. (p. 436-7)

Diadorim, Diadorim, oh, ah, meus buritizais levados de verdes...

(p. 453)

Não à-toa o narrador repisa diversas vezes o verde dos olhos de Diadorim. As menções a seu aspecto líquido e luminoso - "olhos de onda do mar", cujo "verde mudava sempre, como a água de todos os rios", que "luziam um efeito de calma" - também remetem à qualidade glauca dos olhos de Atena, adjetivo que, como já se mencionou, originalmente significava brilhante, sendo empregado sobretudo para descrever o mar.

A associação de Diadorim com passarinhos é outro viés possível de comparação com Palas Atena, que foi descrita como deusa-pássaro. Na iconografia que subsistiu na pintura sobre cerâmica e no estatuário grego, a deusa olímpica é, não raro, representada como uma deusa alada ou na companhia de uma coruja. Entre suas metamorfoses, consta, no terceiro livro da Odisseia, que Palas tomou a forma de uma águia: "Palas Atena, depois 
que assim disse, partiu-se depressa/sob a figura de uma águia. Espantaram-se todos que a viram" (3.371-2). Em certos cultos, ademais, Palas era qualificada pelo epíteto aíthyia, que significa mergulhadora e, para alguns comentadores, seria uma referência a espécies de pássaros mergulhões.

Já na primeira aparição de Diadorim em Grande sertão: veredas, se estabelece uma relação, por contiguidade, entre a personagem e aves: "Conforme pensei em Diadorim. So pensava era nele. Um joão-de-barro cantou. Eu queria morrer pensando em meu amigo Diadorim, mano-oh-mão, que estava Serra o Pau-d'Arco, quase na divisa baiana, com nossa outra metade dos sô-candelários... Com meu amigo Diadorim me abraçava, sentimento meu ia-voava reto para ele" (p. 13). No trecho, pensamentos de Diadorim se emaranham com o canto do passarinho, e os sentimentos provocados por Diadorim voam.

Em outras tantas passagens, a presença da personagem é marcada igualmente por figurações de pássaros. Seu apelido carinhoso, por exemplo, ao ser pronunciado pelo jagunço Quispe, ganha a corruptela "Dindurinh', boa apelidação", como se "fosse o nome de um pássaro" (p. 502). Em certos trechos, o canto de pássaros anuncia a sua chegada, “Demorei bom estado, sozinho, em beira d'água, escutei um fife dum pássaro: sabiá ou saci. De repente, dei fé, e avistei: era Diadorim que chegando, ele já parava perto de mim" (p. 206). Em outros, as lembranças dela são conotadas por verdadeiros inventários de aves:

O rio, objeto assim a gente observou, com uma crôa de areia amarela, e uma praia larga: manhã-zando, ali estava re-cheio em instância de pássaros. O Reinaldo mesmo chamou minha atenção. O comum: essas garças, enfileirantes, de toda brancura; o jaburu; o pato-verde, o pato-preto, topetudo; marrequinhos dançantes; martim-pescador; mergulhão; e até uns urubus, com aquele triste preto que mancha. Mas, melhor de todos - conforme o Reinaldo disse - o que é o passarim mais bonito e engraçadinho de rioabaixo e rio-acima: o que se chama o manuelzinho-da-crôa. (p.122) Eu tornei a me lembrar daqueles pássaros. $\mathrm{O}$ marrequim, a garrixado-brejo, frangos-d'água, gaivotas. O Manuelzinho da crôa. Diadorim, comigo. As garças, elas em asas. (p. 250)

Os quem-quem, aos casais, corriam, catavam, permeio às reses, no liso do campo claro. Mas nas árvores, pica-pau bate e grita. E escutei o barulho, vindo do dentro do mato, d e um macuco sempre solerte. (p. 253)

E a lá se dão os pássaros: de todos os mesmos prazentes pássaros do Rio das Velhas, da saudade - jaburú e galinhol e garça-branca, a garça-rosada que repassa em extensos no ar, feito vestido de mulher... E o manuelzinho-da-crôa, que pisa e se desempenha tão 
catita — o manuelzinho não é mesmo de todos o passarinho lindo de mais amor?...

Podia ser? Impossivelmente. (p. 520)

As aves figuradas no romance acabam emprestando a Diadorim algo de sua natureza, "a vivo, o arisco do ar: o pássaro, aquele poder dele" (p. 156).

Ainda em outros passos, o amor de Riobaldo por Diadorim ganha aspecto e coloração de aves, "Abracei Diadorim como as asas de todos os pássaros” (p. 31); "Eu devia de ter principiado a pensar nele do jeito de que decerto cobra pensa: quando mais-olha para um passarinho pegar" (p. 254). Num deles, interessante para este exercício de rastrear analogias com Palas Atena, Diadorim surge como suindara, espécie de coruja: "E, de manhã, os pássaros que bem-me-viam todo tal tempo. Gostava de Diadorim, dum jeito condenado; nem pensava mais que gostava, mas aí já sabia que gostava em sempre. Ooi suindara! - linda cor...” (p. 78). Mesmo no colorido da suindara, Riobaldo vislumbra a alvura tão identificada com Diadorim no correr das páginas, "a suindara é tão linda, nela tudo é cor que nem tem comparação nenhuma, por cima de riscas sedas de brancura" (p. 352). Os macucos também fazem as vezes de representação amorosa:

Era mês de macuco passear solitário, macho e fêmea desemparelhados, cada um por si. [...] Eu ri - "Vigia este, Diadorim!" - eu disse; pensei que Diadorim estivesse em voz de alcance. Ele não estava. O macuco me olhou, de cabecinha alta. Ele tinha vindo quase indireito em mim, por pouco entrou no rancho. Me olhou, rolou os olhos. Aquele pássaro procurava o quê? Vinha me pôr quebrantos. (p. 253)

Nesse trecho, o desemparelhamento e a solidão do macuco reverberam no íntimo de Riobaldo.

Outro passarinho, o manuelzinho-da-crôa, é evocado várias vezes para sugerir o amor entre os dois jagunços:

Era o manoelzinho-da-crôa, sempre em casal, indo por cima da areia lisa; eles altas perninhas vermelhas, esteiadas muito atrás traseiras, desempinadinhos, peitudos, escrupulosos catando suas coisinhas para comer alimentação. Machozinho e fêmea - às vezes davam beijos de biquinquim - a galinholagem deles. - "É preciso 
olhar para esses com um todo carinho...” Reinaldo disse. Era. Era. Mas o dito assim bota surpresa. E a maciez da voz, o bem querer sem propósito, o caprichado ser - e tudo num homem-d'armas, brabo bem jagunço - eu não entendia. (p. 122)

O lamento elegíaco de Riobaldo por Diadorim muitas vezes lançará mão de alusões ao pássaro.

Há um terceiro epíteto de Palas Atena, tritogenéia, nascida em Trito, relevante neste contexto. $\mathrm{O}$ dicionário Liddell-Scott-Jones registra diferentes explicações para a origem do epíteto. Segundo alguns, seria uma referência ao lago Trítonis, na Líbia, onde a deusa teria nascido. Outros testemunhos afirmam se tratar de uma correnteza na Boécia ou uma fonte em Arcádia. Outros atestam ainda que Tritão seria uma divindade marítima, filho de Poseidon. O radical tríton abarcava, portanto, diferentes termos relacionados a água.

Em Grande sertão: veredas, há todo um conjunto de metáforas que compara Diadorim com rios, veredas, chuva e mar. Como já se mencionou, Riobaldo descreve os olhos de Diadorim como "olhos de onda do mar", cujo "verde mudava sempre, como a água de todos os rios". O narrador também assemelha a presença dela com a chuva, por efeito de contiguidade:

Diadorim e eu, nós dois. [...] Puxava uma brisbisa. O ianso do vento revinha com o cheiro de alguma chuva perto. [...] Por mim, só, de tantas minúcias, não era o capaz de me alembrar, não sou de à parada pouca coisa; mas a saudade me alembra. Que se hoje fosse. Diadorim me pôs o rastro dele para sempre em todas essas quisquilhas da natureza. Sei como sei. [...] Diadorim, duro sério, tão bonito, no relume das brasas. (p. 20)

E, de tardinha, quando voltou o vento, era um fino soprado seguido, nas palmas dos buritis, roladas uma por uma. E o bambual, quase igualmente. Som bom de chuvas. Então, Diadorim veio me fazer companhia. (p. 38)

Em outros passos, o pensamento amoroso em Diadorim confunde-se com a chuva: “'Diadorim, meu amor...' [...] o pensamento dele que em mim escorreu figurava diferente [...], como quando a chuva entre-onde-os-campos" (p. 254). A personagem emerge igualmente como rio, "Diadorim, os rios verdes" (270); "Diadorim, esse, o senhor sabe 
como um rio é bravo?" (p. 376); “Diadorim (...) a voz dele se paliava (...) feito o sussurro, nessas veredas, mão mansa, de tardinha, descabelando o buritizal" (p. 351); "Diadorim, comigo. As garças, elas em asas. O rio desmazelado, livre rolador" (p. 250); “Diadorim — ele ia para uma banda, eu para outra, diferente; que nem, dos brejos dos Gerais, sai uma vereda para o nascente e outra para o poente, riachinhos que se apartam de vez, mas correndo, claramente, na sombra de seus buritizais" (p. 482). Nesse conjunto, as diferentes qualidades fluviais evocadas - a cor verde, a braveza, o sussurro, o movimento rolador parecem operar como metáfora para o movimento de paixões e sentimentos que impulsam a narrativa.

\section{Diadorim belígera}

No plano episódico, também há paralelos possíveis entre Diadorim e Palas Atena. Assim como a deusa olímpica, Diadorim surge como sertaneja belígera, encarnando as virtudes guerreiras. Arigucci Júnior aponta Diadorim como epítome do Sertão e da guerra que nele se desdobra: "de súbito, se descortina, com a evocação de Diadorim e da paisagem, o grande sertão: o vasto mar da guerra jagunça, que é o espaço épico propriamente dito" (1994, p. 23). Há assim uma imbricação entre a terra, a luta e o jagunço na personagemsíntese do romance.

São várias as passagens que descrevem as qualidades guerreiras de Diadorim:

E ele suspirava de ódio, como se fosse por amor... Diadorim só falava nos extremos do assunto. Matar, matar, sangue manda sangue. (p. 21)

O Reinaldo. Diadorim, digo. Eh, ele sabia ser homem terrível. Suspa! O senhor viu onça: boca de lado e lado, raivável, pelos filhos? Viu rusgo de touro no alto campo, brabejando; cobra jararacussu emendando sete botes estalados; bando doido de queixadas se passantes, dando febre no mato? E o senhor não viu o Reinaldo guerrear! (p. 136)

De ver Diadorim, que em febre de acertar e executar, não tomava em si muita cautela, só forcejava por vinganças - punições maravilhosas. Diadorim, mesmo, a cara muito branca, de da alma não se reconhecer, os olhos rajados de vermelho, o encovo. Aquilo era o crer da guerra (p. 310). 
Mesmo o emprego recorrente do adjetivo "belo" para descrever Diadorim parece jogar com a homofonia de duas palavras; assenta a beleza da personagem, mas guarda também o radical "belo-", derivado do termo latim "bellum”, que significa "guerra”.

Ainda no contexto da caracterização de Diadorim como representação do furor da guerra, é interessante o contraste a que a sua maneira de fazer guerra se presta com relação ao guerrear violento e cruel do jagunço Hermógenes. A esse respeito, Márcia Tiburi sugere ser Diadorim “contraposição direta a Hermógenes, personagem que simboliza a barbárie, a imoralidade, o mal maligno que destrói sem repor" (p. 193, n. 7). Para meu argumento, é interessante acrescentar que o contraste entre Diadorim e Hermógenes espelha a oposição entre Atena e Ares na condução da guerra. No tocante a Diadorim, depreendese, da leitura da obra, sua esperteza - há duas ocorrências do termo "esmarte" para descrevê-la (p. 81 e p.327) -, cautela e astúcia, conforme a citação transcrita a seguir: "Entremeio, Diadorim se maisfez, avançando passo. Deixou de me medir, vigiou o ar de todos. Aí ele era mestre nisso, de astuto se certificar só com um rabeio ligeiro de mirada - tinha gateza para contador de gado" (p. 67). Por seu turno, as práticas sanguinárias de Hermógenes e seu bando são descritas em diversos momentos de Grande sertão: veredas, a exemplo da seguinte passagem: "Mas os hermógenes e os cardões roubavam, defloravam demais, determinavam sebaça em qualquer povoal à-toa, renitiam feito peste” (p. 45).

À divergência moral entre as persoangens, corresponde outra física. A deformidade e estranheza do jagunço cruel se revela em sua aparência:

O outro - Hermógenes - homem sem anjo-da-guarda. Na hora, não notei de uma vez. Pouco, pouco, fui receando. O Hermógenes: ele estava de costas, mas umas costas desconformes, a cacunda amontoava, com o chapéu raso em cima, mas chapéu redondo de couro, que se que uma cabaça na cabeça. Aquele homem se arrepanhava de não ter pescoço. As calças dele como que se enrugavam demais da conta, enfolipavam em dobrados. As pernas, muito abertas; mas, quando ele caminhou uns passos, se arrastava [...]. (p. 98)

São essas as primeiras impressões de Riobaldo a respeito de Hermógenes, em seguida à apreciação da beleza magnânima de Joca Ramiro, quando de sua estada na Fazenda São Gregório, de Selorico Mendes. 
Como dito acima, tal contraste remete à oposição entre Atena e Ares, na tradição antiga, como representações de maneiras distintas de fazer guerra. Ao lutar, Palas - em algumasteogonias, filha de Métis (que significa "inteligência prática") - seria movida por um espírito inteligente, prático e racional, impulsionando ações estratégicas e táticas no âmbito bélico. Ares, ao contrário, sentia prazer em matança, sangue e destruição, permanecendo indiferente a quaisquer considerações sobre justiça, fazendo-se acompanhar, por Deimo (Terror), Fobo (Medo), Ênio (Deusa da Guerra) e Éris (Discórdia) nas batalhas (Rodríguez, 2015, p. 16). Recorde-se que, na Ilíada, Atena e Ares se alinham a lados diferentes na guerra, Atena protege os aqueus, enquanto Ares defende os troianos.

Em suma, a ênfase do narrador na astúcia, na esperteza e no páthos belígero de Diadorim parece inspirar-se no guerrear de Palas, deusa que de alguma maneira torna à vida no Sertão.

\section{A neblina de Diadorim}

Um terceiro viés de aproximação entre Diadorim e Palas Atena está na metáfora da neblina. Ao longo de Grande sertão: veradas, Riobaldo lança mão de "neblina" e variações (“nublo", “neblim”, “garoa”, “xererém”, “nuvem”) para expressar os sentimentos provocados por Diadorim. Também esse uso remete à poesia épica antiga. Com efeito, na Ilíada e na Odisséia, a neblina é um recurso empregado vezes sem conta por Atena e outros deuses, para velarem a si próprios e a seus mortais diletos nas batalhas. Atena é uma das deusas que se vale frequentemente da dissimulação das nuvens: na Ilíada, a deusa desce até o teatro da guerra envolta em "nuvem rutilante" (17:551), oculta-se numa nuvem escura ao ajudar Diomedes no embate (5.186) e tece uma nuvem dourada em volta da cabeça de Aquiles para coroá-lo (18:205-206); na Odisseia, em pelo menos três ocasiões, a deusa lança em torno de Ulisses uma neblina espessa para ocultá-lo (7:14, 7:140 e 13:19o).

Além de artifício de proteção, a neblina é também metáfora para certa cegueira dos mortais. No livro 5 da Ilíada, por exemplo, na "Aristeia de Diomedes", Palas levanta a "neblina" que impede Diomedes de ver claramente, o que lhe permite distinguir deuses e mortais no combate (5:127). No livro 15 (15:66-671), semelhantemente, a deusa "afasta a nuvem de neblina imortal" dos olhos dos gregos, aguçando a sua percepção. Há, ainda, em Homero, a conotação sentimental de termos do campo semântico da neblina. 
Primeiramente, a expressão "nuvem (nephéle) escura de mágoa" tem pelo menos duas ocorrências na Ilíada (17:591, 18:22). Em segundo lugar, a morte é descrita como uma neblina ou nuvem que envolve o moribundo: Aiken atesta cinco ocorrências na Ilíada, alternando-se os termos axlús (5:696, 16:344, 20:421), néphos (16:350), e nephéle (20:417). Em terceiro lugar, Aiken ressalta seu uso amatório, ao evocar a nuvem dourada formada por Zeus para proteger o encontro amoroso com a esposa Hera de olhares mortais e divinos (14:340-351).

Riobaldo vale-se de termos do campo semântico da neblina em passagens alusivas a Diadorim, explorando poeticamente sua polissemia. Emprega-os quer com sentidos semelhantes aos dos épicos antigos, quer com matizes literários diferentes. Em certos passos, a neblina torna manifesta a cegueira de Riobaldo com relação a Diadorim, a sua incapacidade de perceber o sexo de sua companheira. Talvez por isso a associação de Diadorim com neblina venha condicionada pela conjunção adversativa "mas" na primeira ocorrência no romance: "Amor vem de amor. Digo. Em Diadorim, penso também - mas Diadorim é a minha neblina..." (p. 16). Nesse sentido, Riobaldo lamenta: “Ah, tem uma repetição, que sempre outras vezes em minha vida acontece. Eu atravesso as coisas - e no meio da travessia não vejo" (p. 26). Em outro passo, a névoa surge como metáfora para o esquecimento, "a ser que se nublando a sustância da recordação" (p. 360). Mais para o final, a neblina ressurge como representação de certa cegueira, desta vez não de amor mas de ódio. Riobaldo, ao tentar figurar Hermógenes, o percebe "assim neblim-neblim, mal vislumbrado" (p. 477).

No levantamento de passagens sobre neblina ou nuvens em Grande sertão: veredas, a conotação mais frequente é amorosa. A neblina como símile de sentimentos amorosos guarda nuanças: compreende provável referência ao bordão de que o amor é cego; implica o jogo de velar e desvelar entre amantes, que sondam mistérios mútuos; diz algo da efemeridade e da tristeza do amor perdido e da morte, olhos nublados; talvez refira ainda trocas eróticas, sugeridas pelo movimento e pela cor branca da neblina. Riobaldo vale-se do termo "nublo" para descrever a primeira experiência de cegueira amorosa, quando, jovenzinho, se inteirou do noivado da mocinha Rosa'uarda com um comerciante turco, "Assumi, em trela, tristeza e alívio - aquele amor não seria mesmo para mim, pelos motivos pessoais. Nublo em que me vi" (p. 105). Ao inventariar amores - Diadorim, Nhorinhá, Rosa'uarda, Miosótis - Riobaldo volta a utilizar a metáfora da neblina, desta vez em provável referência à efemeridade e volatilidade da névoa de sentimentos: "Mas o mundo 
falava, e em mim tonto sonho se desmanchando, que se esfiapa com o subir do sol, feito neblina noruega movente no frio de agosto" (p. 277).

Mas a neblina traduz também experiências menos etéreas, de cunho sexual. No reencontro de Riobaldo e Diadorim, anos depois de se conhecerem na infância, no porto do de-Janeiro, a neblina será ressignificada nessa linha: "Eu vi a neblina encher o vulto do rio e se estralar da outra banda a barra da madrugada” (p. 121). A passagem insinua algo de erotismo que tensionará a relação entre os dois jagunços, a neblina surgindo como metonímia seminal.

Transcrevo, a seguir, mais alguns trechos, dos quais se depreendem os diferentes sentidos amorosos da neblina:

A garoa rebrilhante da dos-Confins, madrugada quando o céu embranquece - neblim quem chamam de xererém. Quem me ensinou a apreciar essas as belezas sem dono foi Diadorim... (p. 18) Mas os olhos verde sendo os de Diadorim. Meu amor de prata e meu amor de ouro. De doer, minhas vistas bestavam, se embaçavam de renuvem, e não achei acabar para olhar para o céu. (p. 41)

E foi ele mesmo, no cabo de três dias, quem me perguntou: "Riobaldo, nós somos amigos, de destino fiel, amigos?" "Reinaldo, pois eu morro e vivo sendo amigo seu!" - eu respondi. Os afetos. Doçura do olhar dele me transformou para os olhos de velhice da minha mãe. Então, eu vi as cores do mundo. Como no tempo em que tudo era falante, ai, sei. De manhã, o rio alto branco, de neblim; e o ouricuri retorce as palmas. (p. 127)

A neblina deixa assim de ser elemento de paisagem para se tornar um motivo carregado de significação emocional e física.

Mesmo o desenlace trágico de Diadorim, morta em combate por Hermógenes, ganha conformação nebulosa. Riobaldo parece adivinhar o que se passará: "Porque era dia de antevéspera: mire e veja. Mas isso, tão em-pé, tão perto, ainda nuveava, nos ocultos do futuro" (p. 497). O presságio se consuma em descrição novamente carregada de nuvens: 
Como, de repente, não vi mais Diadorim! No céu, um pano de nuvens... Diadorim! Naquilo, eu então pude, no corte da dor: me mexi, mordi minha mão, de redoer, com ira de tudo... Subi os abismos [...]. Eu estou depois das tempestades. [...] Diadorim tinha morrido - mil-vezes-mente - para sempre de mim; e eu sabia, e não queria saber, meus olhos marejavem. (p. 527-528).

As nuvens inauspiciosas são internalizadas pelo narrador, cujos olhos "marejavam". Riobaldo se perderá na neblina de morte e amor frustrado.

\section{O Sertão mitificado em Rosa e na tradição sertaneja}

Permito-me dedicar esta seção ao processo de mitificação literária do Sertão em Guimarães Rosa e seus predecessores. O sentido desse exercício é inserir o paralelo entre Diadorim e Palas Atena no contexto maior de figuração da terra sertaneja como locus imaginário em que o humano e o histórico esbarram com o mítico e o divino. Com efeito, como foi dito na seção IV, Diadorim pode ser tomada como personagem epítome do Sertão, sintetizando contradições como amor e ódio, feminino e masculino, e mesclando elementos humanos e divinos, como transitoriedade e permanência. Ao interiorizar as dualidades que marcam a vida sertaneja, Diadorim transcende, mas também se confunde com a própria terra. Por esse motivo, a discussão que segue é relevante para o entendimento de quem é, afinal, Diadorim.

Ao recriar uma topografia mítica no recorte geográfico dos "Gerais", habitados pelo divino e pelo humano, Guimarães Rosa é devedor da tradição que o antecedeu. Objeto de literatura desde os primeiros tempos da colonização, o Sertão foi percorrido e descrito por cronistas e viajantes ainda nos séculos XVI e XVII. Se, em sua maioria, seus relatos manifestaram uma orientação naturalista, buscando registrar paisagem, relevo, clima, flora e fauna, alguns desses primeiros escritos já operaram uma transformação simbólica da região. Como aponta Sérgio Buarque de Holanda em Visões do Paraíso, as terras brasileiras 
foram tomadas por certos cronistas como espécie de jardim edênico (e, por outros, como inferno ou purgatório) $)^{4}$.

Alguns séculos mais tarde, o romantismo brasileiro volta-se novamente para o Sertão. A exemplo da literatura de viajantes, sua apreciação da terra passa pela valorização da natureza. Mas, em vista do contexto de independência e formação nacional, o Sertão ganha implicações políticas, surge como locus de origem de uma proto-nacionalidade. Em obras como O guarani, Iracema e O sertanejo, José de Alencar ressignifica-o como espaço de origem, seja pessoal, no âmbito biográfico e afetivo, seja nacional, num registro mais mítico que histórico da formação do povo brasileiro ${ }^{5}$. Em que pesem os anseios do romantismo brasileiro em contribuir com a formação de um imaginário nacional que servisse aos fins de consolidação da unidade regional, política e racial do Império, a terra nem sempre se reduziu a espaço de construção programática. Alencar, por exemplo, imbuiu seus romances das contradições que marcaram a formação do Brasil. Como aponta Luiz Valente, “imagens edênicas coexistem com a figuração de violação, morte e destruição" (1993, p. 160).

No século XX, em Os sertões de Euclides da Cunha, o Sertão se desdobrará em espaço múltiplo de representação. Euclides revisita obras dos cronistas e românticos, incorporando algo da orientação naturalista. Manifesta uma preocupação quase científica com a formação da terra sertaneja, tomando de empréstimo teorias e vocabulários das ciências naturais. A morfologia da "terra ignota" é estetizada, e o linguajar científico ganha coloridos literários e dramáticos a fim de se construir um cenário pictórico-teatral para a batalha de Canudos, como sustenta Zilly (1998).

As descrições geográficas entremeiam-se com a História. Os longos ciclos geomórficos contrastam com a brevidade da existência histórica humana e, ao mesmo tempo, desvelam a fragilidade da vida. Já na "Nota preliminar", Euclides afirma que escreve “ante o olhar de futuros historiadores" (p. 99) e, em diversos momentos, incorpora digressões historiográficas. Ao descrever a "sub-raça” sertaneja, cabocla, forte, Euclides parece subscrever ao projeto romântico de identificar na amálgama das raças a brasilidade,

\footnotetext{
${ }^{4}$ A título de exemplo, no século XVII, Antônio Pinelo teria avançado a hipótese de que o paraíso terreal se encontrava no centro da América do Sul, com sua sugestiva forma de coração. Para o autor obscuro, os quatro rios do paraíso mencionados no Gênese não seriam outros que o Amazonas, o Orinoco, o Prata e o Madalena. Ainda segundo Pinelo, Adão e Eva teriam caído não por provar da maçã, do figo ou da banana, como queriam alguns, mas sim do maracujá (Buarque de Holanda, p. XX-XXI).

${ }^{5}$ De maneira exemplar, em Iracema, o romancista elege o sertão cearense - terra natal a que dedica a obra - como lugar de encontro entre a tabajara Iracema e o português Martim, que teriam gerado o primeiro brasileiro, Moacir, nascimento esse conotado pelo sofrimento e pela morte materna.
} 
mas sempre com um viés crítico. Se românticos como Alencar apenas sugerem a violência por trás do projeto de formação nacional, Euclides a explicita: considera que a campanha de Canudos foi um “crime”, um esmagamento de nossos "irmãos retardatários".

Cumpre notar ainda que esse registro que se quer científico e histórico é objeto de estilização literária, em que as camadas narrativas e emocionais vão se revelando à maneira de estratos geológicos. Ao dar o seu testemunho sobre a "Troia de taipa dos jagunços" (p. 171), Euclides se aproxima da tradição épica. Com efeito, como observa Valente, o autor pretere a pretendida neutralidade histórica para adotar "um ponto de vista coletivo, 'nós filhos do mesmo solo', (...) esse ponto de vista coletivo seria, em princípio, mais apropriado ao poema épico ou à literatura de fundação romântica, do que à narrativa histórica de inspiração positivista, que aspirava à impessoalidade e à objetividade" (1998, p. 47).

Sob uma perspectiva mais mística, Euclides foi o primeiro autor a realçar os aspectos simbólicos e religiosos do embate em Canudos. Percebeu que, ao contrário do que queria a imprensa urbana de sua época, a "guerra" não havia sido motivada apenas por conflitos fundiários e fiscais ou por dissidências monarquistas. Anseios religiosos e ideais utópicos alentaram o movimento liderado por Antônio Conselheiro, que contou com a adesão fervorosa de dezenas de milhares de sertanejos. A esperança de recriar o paraíso terreal no interior do Brasil e de recuperar um estado de felicidade "pré-lapsária" retoma mitos messiânicos e sebastianistas consagrados das tradições de literatura oral e escrita do Sertão, que remontam ao século XVII.

A possibilidade de criação de novas estruturas sociais no Sertão passará, assim, a integrar o imaginário brasileiro. Nem sempre, é verdade, com fundamentação mística ou religiosa. É esse o caso de Graciliano Ramos, que situa a utopia em bases mais políticas e sociais. Em obras como Angústia e Vidas secas, a ação e a vontade pessoal são apontadas como meio de alteração das estruturas sociais. Em outras, como São Bernardo, em que pese a ausência de ação transformadora, observa-se a tomada de consciência do narradorprotagonista, que parece abandonar os valores burgueses e a vida orientada para a acumulação de capital. Se os ideais utópicos não chegam a se consumar nos romances de Graciliano, o desenlace trágico não se perde na economia de cada uma dessas obras. Como estratégia literária, as transformações sugeridas favorecem reavaliações críticas da parte dos leitores. A tensão entre a obra e o mundo prenuncia, portanto, no plano extraliterário, a possibilidade de se fundar uma sociedade mais justa. 
Voltando a Guimarães Rosa, sua obra é, por um lado, devedora da literatura de cronistas e viajantes na medida em que lança mão, em diferentes passagens, da técnica do inventário para realizar um registro poético da geografia, da flora e fauna sertaneja (cf., por exemplo, o conto "São Marcos", em Sagarana). Por esse recurso, alcança uma representação sintética da realidade, mostrando a multiplicidade na unidade. Além de incorporar técnicas e linguagem das ciências naturais, são também retomadas as figurações místicas da terra brasileira já presentes nos escritos de certos cronistas. Por outro lado, Rosa manifesta preocupações com o povo, história e nação, de verve mais romântica ou euclidiana.

Apesar de inserir-se numa tradição que remonta ao século XVI, não restam dúvidas sobre a originalidade do tratamento que Guimarães Rosa dispensou ao Sertão brasileiro. Em seus escritos, preocupações com princípios, origem e criação adquirem um estatuto mais filosófico e reflexivo. Assim como seu personagem Riobaldo, o autor mineiro inventou-se "neste gosto, de especular ideias" (1986, p. 3). O autor enveredou-se por cogitações sobre metafísica, ontologia, unidade e multiplicidade, o problema do bem e do mal, linguagem e representação, entre outras. Sua obra pode ser lida como um caleidoscópio em que diferentes teorias e visões de mundo justapõem-se e vão sendo rearranjadas nos movimentos erráticos da narrativa. Em resumo, ainda segundo Valente, "Sem dúvida um elemento fundamental na obra de Guimarães Rosa, a eterna procura pelo conhecimento consubstancia-se no motivo onipresente da travessia" (2011, p. 29).

Em seus dois romances Corpo de baile e Grande sertão: veredas, o exercício de compreensão da realidade traduz-se numa verdadeira cosmogonia, que de alguma maneira confina com as teogonias antigas. Segundo Candido, trata-se de uma "invenção baseada num ponto de partida em que tudo estivesse no primórdio absoluto, na esfera do puro potencial. Parece que o autor quis e conseguiu elaborar um universo autônomo e composto de realidades expressionais e humanas que se articulam em relações originais e harmoniosas" (1994, p. 78)

Além de incorporar ideias fundacionais em suas narrativas, Rosa empreendeu algo como uma cosmogonia formal: procedeu a uma recriação do mundo no âmbito linguístico.

\footnotetext{
${ }^{6}$ Em Corpo de Baile, por exemplo, parece-me que as novelas ilustram explicações concorrentes sobre os princípios primeiros: o embate entre opostos ("Campo geral"), o mundo como fluxo ("Uma história de amor"), a harmonia das esferas ("Recado do morro"), a criação pelo verbo ("Cara de bronze"), a ascensão pelo amor ("A estória de Lélio e Lina"), a tensão entre realidade e imaginação ("Dão-Lalalão") e os instintos de criação e procriação ("Buriti”).
} 
A respeito, disse a Günter Lorenz que "somente renovando a língua é que se pode renovar o mundo" (p. 52) e que "a poesia se origina de modificações de realidades linguísticas" (p. 56). Por meio do recurso criativo a técnicas neológicas como aglutinação, afixação, neologismo, etimologia, analogia, polissemia, G. Rosa depurou as palavras, realizando, a meu ver, uma "onomotagonia" ou invenção verbal do mundo. Mas também reservou um espaço nesse universo para o silêncio e o inefável. Segundo Sônia Viegas, "Os desvãos de silêncio entre as palavras consomem na angústia e na incerteza a existência humana" (p. 8).

Em suma, como observou Eduardo Coutinho,

O sertão, a paisagem que dá forma a suas narrativas, é não apenas a recriação literária de uma área geográfica específica, tanto em seus aspectos físicos quanto socioculturais, mas também, e principalmente, a representação de uma região humana, existencial, viva e presente na mente de seus personagens - uma região que só pode ser definida como um microcosmo. (...) $\mathrm{O}$ sertão [é] conscientemente construído na linguagem, ou seja um universo que ultrapassa a pura referencialidade e se institui como espaço eminente da criação (p. 17-19).

Nessas linhas, a recriação não-mimética do Sertão como microcosmo autônomo e simbólico resulta numa literatura filosófica, e não surpreende que no enredo imbriquemse fios de narrativas teogônicas, em que personagens que mesclam características divinas e humanas codificam certos aspectos da realidade e da natureza, a exemplo de Diadorim, que, como tentei mostrar, incorpora traços da deusa Palas Atena. Enquanto espaço imaginário, o Sertão nos permite esquadrinhar as questões originárias que nos preocupam, para as quais, na ausência de respostas finais, a literatura oferece caminhos diegéticos de resolução afetiva e poética.

\section{Conclusão}

Nesse artigo, procurei coligir elementos de caracterização de Diadorim que remetem a Palas Atena. Do exame das muitas passagens retomadas, depreende-se que 
Guimarães Rosa se apropriou da tradição em torno da deusa olímpica para a composição da personagem sertaneja, ressignificando-a e concedendo-lhe sentidos e matizes novos.

Com efeito, as glosas rosianas de motivos da épica clássica dão lugar a reflexões sobre guerra, amor, natureza e morte de inflexão sertaneja.

No romance, o tópos da deusa virgem se encontra cifrada no canto de Siruiz, que, como atenta Luiz Roncari, presta-se a roteiro de leitura da obra, uma vez que "predizia e resumia a história" da vida de Riobaldo, àquela altura, ainda por viver (p. 285). O canto é referido por Riobaldo, pela primeira vez, quando relata a visita de Joca Ramires à fazenda São Gregório. Na ocasião, perguntam ao jagunço: "Siruiz, cadê a moça virgem?” (p. 101). Siruiz põe-se a cantar. A Riobaldo, de início, a "toada" parece "toda estranha" (p. 101). Mas o narrador guarda os versos "no giro da memória" (p. 103). A seu amigo Garanço, Riobaldo confessa que Siruiz "cantava cousas que a sombra delas em meu coração decerto já estava. O que eu queria saber não era próprio do Siruiz, mas a moça virgem, moça branca, perguntada, e dos pés-de-verso como eu nunca tive poder de formar igual” (p. 152). A moça virgem e branca não deve ser outra que Diadorim, de "corpo claro e virgem de moça" (p. 165).

O canto de Siruiz é retomado diversas vezes por Riobaldo, que chega mesmo a dar o nome do jagunço-aedo a seu cavalo. Em um desses passos, ao meditar sobre as neblinas do seu amor por Diadorim, Riobaldo aduz: "A vida é muito desencontrada. Tem partes. Tem artes. Tem as neblinas de Siruiz. Tem as caras todas do Cão e as vertentes do viver" (p. 445).

\section{Referências Bibliográficas}

AIKEN, D. (2001). Praxis hermeneutika.: A study in the obscuring of the divine: Mists and clouds in Homer's iliad." Existentia - a Journal of Classical and Hermeneutical Studies, vol. XI, p. 277-296.

ALENCAR, J.de. (1965). Iracema. Obras Completas, vol. III. Rio de Janeiro: Nova Aguilar. (1965). O guarani. Obras Completas, vol. II. Rio de Janeiro: Nova Aguilar. (1965). O sertanejo. Obras Completas, vol. III. Rio de Janeiro: Nova Aguilar. 
ARRIGUCCI JÚNIOR, D. (1994). O mundo misturado: romance e experiência em Guimarães Rosa. Novos Estudos/CEBRAP, São Paulo, n. 4o, p. 7-29.

BATISTA, E. R. (2016). Análise comparativa entre as donzelas guerreiras Diadorim e Monja Alferez. Interdisciplinar-Revista de Estudos em Língua e Literatura, vol. 25, p. 157-168.

BUARQUE DE HOLANDA, S. (2007). Visão do paraíso. São Paulo: Brasiliense.

CANDIDO, A. (1994). O homem dos avessos. In: Guimarães Rosa, João. Ficção completa, vol. 1. Rio de Janeiro: Nova Aguilar. p. 78-92.

COSTA, A. L. M.(2001/2002). Homero no Grande Sertão. Kléos, n. 5/6, p. 79-124. (2002). Diadorim, delicado e terrível. Scripta, vol. 5, n. 10, p. 38-52.

COUTINHO, E. F. (1994). Guimarães Rosa: um alquimista da palavra. In: Guimarães Rosa, João. Ficção completa, vol. 1. Rio de Janeiro: Nova Aguilar, p. 11-24.

CUNHA, E. da.(1995). Os sertões. Obras Completas, vol. II. Rio de Janeiro: Nova Aguilar. GUIMARÃES ROSA, J. (1986). Grande sertão: veredas. Rio de Janeiro: Nova Fronteira. (1978). Sagarana. Rio de Janeiro: José Olympio. (1994). Corpo de baile. Obras Completas, vol. I. Rio de Janeiro: Nova Aguilar.

HOMERO. (2001/2002). Ilíada, volumes I e II. Tradução de Haroldo de Campos. São Paulo, Arx. (2001). Odisséia. Tradução de Carlos Alberto Nunes. Rio de Janeiro: Ediouro.

IANNACE, R. (1999). "Viril sagacidade": um distinto contorno feminino. Via Atlântica, vol. 2, p. $270-275$.

LORENZ, G.(1994). Diálogo com Guimarães Rosa. In: Guimarães Rosa, J.. Ficção completa, vol. 1. Rio de Janeiro: Nova Aguilar, p. 25-61.

LUKACS, G. (1970) Narrate or describe?. Writer and Critic and Other Essays. Merlin Press, p. $110-148$.

MACHADO, F. (2007). Corpo 'Neblim': a representação do corpo de Diadorim em Grande sertão: veredas. Em Tese, vol. 11, p. 47-51. 
NUNES, B. (1994) O amor na obra de Guimarães Rosa. In: Guimarães Rosa, J.. Ficção completa, vol. 1. Rio de Janeiro: Nova Aguilar, p. 112-133.

RAMOS, G. (1984). Angústia. Rio de Janeiro: Record. . (1983). São Bernardo. Rio de Janeiro: Record. (1986). Vidas secas. Rio de Janeiro: Record.

RODRÍGUEZ, S. B. (2005). Ares el dios más odiado del olimpo griego. Minius, vol. 13, p. 1526.

SELIGMANN-SILVA, M. (2009). Grande Sertão: Veredas como gesto testemunhal e confessional. Alea: Estudos Neolatinos, vol. 11.1, p. 130-147.

TIBURI, M. (2013). Diadorim: biopolítica e gênero na metafísica do Sertão. Rev. Estud. Fem.v. 21, n. 1, p. 191-207.

VALENTE, L. V. (1993). Alencar's Flawed Blueprints. Homenagem a Alexandre Severino: Essays on the Portuguese Speaking World (Ed. Marshall Eakin and Margo Milleret). Austin: Host, 148-166. . (1998). Entre Clio e Calíope: a construção da narrativa histórica”. História, Ciências, Saúde Manguinhos, vol. V (suplemento), p. 39-55. (2011). Mundivivências: leituras comparativas de Guimarães Rosa. Belo Horizonte: Editora UFMG.

VIEGAS ANDRADE, S. M. (1985). A vereda trágica do “Grande sertão veredas”. São Paulo: Edições Loyola.

ZILLY, B. (1998) A guerra como painel e espetáculo - A história encenada em Os sertões. História, Ciências, Saúde, Manguinhos, vol. V (suplemento), p. 13-37. 